\title{
KONTROL POLITIK BIROKRASI DALAM KEBIJAKAN PUBLIK
}

\author{
Mashur Hasan Bisri \\ Universitas Islam Raden Rahmat, Malang \\ Email: hasanbisri79@yahoo.com
}

\begin{abstract}
Separation of powers provides norms and values that make a difference even the never-ending debate about divisions and work programs in the public policy process between politics and administrative that often occur in the system of relationships between the executive and legislative. This separation in politics and administration as a separation of related structural tasks with policy recommendations, regulation and control (control), ownership and distribution of resources, and so on. This happens that bureaucracy often plays for interference in the policy sphere so there is little intervention by bureaucrats to policy matters and is also done by politicians to in administration.Politik and administration as the distribution of values, costs, and profits, as a whole participates in this distribution process and in it the bureaucracy has the opportunity to submit proposals to policy makers, using discretion, the process in the implementation of policies, forming policies formulated by elected officials.
\end{abstract}

Keyword: Bureaucracy; Policy; Political; Administration

\section{PENDAHULUAN}

Didalam bukunya Politics and Administration, Goodnow (1900) berpendapat bahwa ada dua fungsi pokok pemerintahan yang berbeda satu dengan lainnya.Dua fungsi pokok tersebut ialah politik dan administrasi. Politik menurut Goodnow (1900) harus melakukan kebijakan - kebijakan atau melahirkan keinginan, serta kepentingan negara.Sementara administrasi diartikan sebagai sesuatu yang harus berhubungan dengan pelaksanaan kebijakan. Adanya pemisahan kekuasaan memberikan dasar perbedaan bahkan perdebatan mengenai divisi kerja dalam proses kebijakan antara pihak politik dan administratif selalu terjadi. Setelah terbentuknya manajemen publik baru (new public manajemen) definisi keduanya mengalami pembaharuan. Proses reformasi administrasi pada masa NPM (new public manajemen) terdiri atas dua jenis: berasal dari pilihan publik (public choice) dan pemikiran manajerial, sehingga spesialisasi pemerintah daerahakan mengarah pada manajemen dan memberi pelayanan yang lebih baik. Berdasarkan konsep NPM (new public manajemen), tipe yang ideal adalah dengan memisahkan institusi pemerintah daerah dari pusat kekuasaan sehingga di banyak negara yang menganut NPM (new public manajemen) terjadi peningkatan spesialisasi fungsi administratif secara horizontal dengan pemisahan yang jelas antara politik dan administrasi.

Pemisahan politik dan administrasi ini bertujuan untuk sebagai pemisahan tugas struktural yang berkaitan dengan rekomendasi kebijakan, regulasi dan kontrol, kepemilikan, pembelian dan distribusi, dan sebagainya.Hal ini karena NPM (new public 
manajemen) muncul atas respon terhadap birokrasi lama yang menggabungkan pekerjaan kebijakan dan implementasinnya di sebuah sistem administrasi dalam ruang lingkup yang besar. Sehingga diyakini bahwa pihak administratif yang saling berjauhanharus fokus pada implementasi kebijakan daripada terlibat pada proses pengambilan keputusan. Menurut Wilson yang dikutip oleh Frederickson dan Smith (2003) menyimpulkan bahwa birokrasi yang sukses adalah yang eksekutifnya menciptakan misi yang jelas, mengemukakan tugas yang harus dicapai untuk mencapai misi tersebut, menyebarkan otoritas dalam organisasi menurut tugasnya dan memberikan bawahan (khususnya operator) otonomi yang cukup untuk menjalankan tugasnya - sebuah tatanan yang tinggi dalam lingkungan agensi publik yang kompleks.

Namun demikian ada sebuah kesenjangan antara tugas administratif (implementasi kebijakan) dan tugas politik (memutuskan kebijakan), Menurut Crosby dan Brinkrhoff (2002), proses implementasi kebijakan setidaknya bersifat politis, teknis dan kompleks dan sangat interaktif.Sehinggapemerintah daerah berfungsi lebih dekat pada pembuatan keputusan yang dibuat selama tahap implementasi. Sehingga apabila teori ini terbukti, kita akan sedikit menjumpai keterlibatan lembagapemerintah daerah pada proses persiapan dan penetapan siklus kebijakan. Tetapi beberapa ahli berargumen bahwa kebijakan bukanlah fitur utama dari NPM (new public manajemen).

Peran dari pemerintah daerahdalam pembuatan kebijakan dapat dilihat dari peran aktor - aktor stakeholder yang berperan dalam memformulasikan kebijakan.Dimensi partisipasi ini dapat dianggap sebagai pilihan, mulai dari mode yang relatif pasif sampai yang aktif. Selebihnya menurut Crosby dan Brinkerhoff (2002)tipe/jenis partisipasi dapat dibedakan atas beberapa, yakni: a]. Sharing informasi, Arus komunikasi searah. Dilakukan agar aktor kebijakan selalu mendapatkan informasi, menjaga transparansi dan membangun legitimasi, b]. Konsultasi, komunikasi dua arah dan pertukaran pendapat. c]. Kolaborasi, Gabungan kegiatan dimana inisiator mengundang kelompok lain untuk terlibat termasuk kalangan yang berwenang dan memiliki kontrol terhadap pembuatan keputusan, d]. Kerjasama pembuatan keputusan, Kolaborasi menyangkut pembagian kontrol atas pembuatan keputusan yang sangat berguna menyangkut pengetahuan eksternal aktor, kapasitas dan pengalaman merupakan pencapaian tujuan kebijakan, e]. Pemberdayaan, Transfer pengawasan melalui pembuatan keputusan, sumberdaya dan aktivitas dari inisiator ke stakeholder yang lain. Pemberdayaan mengambil tempat ketika aktor eksternal bertindak sendirian atas terhadap kepentingannya sendiri, menangani mandat kebijakan tanpa melibatkan pemerintah.

Tujuan utama dari reformasi organisasi adalah menciptakan pemerintah daerah yang ditata oleh peraturan yang merujuk ke karakter pemerintah dengan tipe ideal normative dan berfokus pada restorasi 'keunggulan politik', sehingga implementasi kebijakan menjadi inti dari tugas pemerintah daerah. Pihak administrative dibatasi untuk 
hanya memberi saran dan implementasinya, bukan terlibat dalam pengambilan keputusan.

Secara singkat dapat dikatakan bahwa suatu usaha untuk menetapkan kembali hubungan konseptual antara administrasi dengan politik. Akan tetapi konsekuensi dari usaha ini ialah keharusan untuk merumuskan bidang ini paling sedikit dalam hubungannya dengan focus keahliannya yang esensial (Toha, 1997). Pihak politik (aktor politik) tampak memiliki peran lebih besar daripada pihak lainnya di tahap proses kebijakan, yang sejalan dengan model normatif. Akan tetapi pihak politik dan administratif sama-sama berpengaruh dalam fase implementasi yang mana bertentangan dengan asumsi policy divide model.

Hasil penelitian Verschuere (2010) yang sejalan dengan penelitian lainnya dimana pemerintah daerah sebagai ekskutif yang terlibat, ikut serta (partisipasi) dalam kebijakan bisa bervariasi, baik dalam program atau fase kebijakan yang merujuk pada peningkatan peran lembaga sector publik dalam membuat pilihan kebijakan. Meskipun secara teori pihak politik dan administratif tidak seharusnya saling mencampuri domain satu sama lain, kenyataanya tidak begitu dimana dalam banyak hal keduanya bekerja bersama.

\section{KAJIAN PUSTAKA}

\section{Birokrasi Pemerintahan}

Menurut Albrow (1996) Birokrasi mempunyai arti sebagai wewenang atau kekuasaan di berbagai departemen pemerintahan dan cabang - cabangnya memperebutkan untuk diri mereka sendiri atas sesame warga negara. Sedangkan birokrasi dalam perspektifnya Hegel merupakan medium yang mempertemukan kepentingan rakyat dan pemerintah, birokrasi mengemban tugas besar berupa harmonisasi hubungan antara rakyat dan pemerintah bahkan mempersamakan geist rakyat dengan geist pemerintah.Kemudian menurut Blau (2000) mendefinisikan birokrasi sebagai suatu lembaga yang sangat kuat dengan kemampuan untuk meningkatkan kapasitas kapasitas potensial terhadap hal - hal yang baik maupun buruk, karena birokrasi merupakan instrument administrasi rasional yang netral dan berskala besar.

Dengan demikian birokrasi merupakan organisasi yang besar yang memiliki ciri - ciri khusus dan universal antara lain mementingkan orientasi tugas, tujuan, pemenuhan tujuan perencanaan, efisiensi, menekankan sistematisasi, akurasi, menunjang verifikasi, kontrol dengan formalitas. Birokrasi berusaha memahami hubungan kekuasaan dan otoritas dalam merumuskan otorita sebagai kekuasaan yang sah.Kepercayaan bawahan terhadap legitimasi akan menghasilkan kestabilan pola hubungan dari perbedaan sumber perintah dalam system organisasi.

\section{Teori Kontrol Politik Atas Birokrasi}

Teori ini merupakan sebuah pendekatan dalam teori administrasi publik yang berhubungan dengan kepatuhan atau respon. Pakar teori kontrol birokrasi menggunakan beberapa bentuk dikotomi politik administrasi (kebijakan administrative). Dikotomi politik administrasi berawal dari asal administrasi publik modern.Dikotomi adalah pemisahan power 
legislative dan eksekutif, karena dikotomi politik administrasi adalah asumsi penting dalam teori kontrol birokrasi.

\section{Perbedaan Antara Politik dan Administrasi dan Urusan Kontrol Birokratik}

Menurut Wilson (1887/1941 dan Goodnow (1900) yang dikutip oleh Frederickson dan Smith (2003) secara sederhana perbedaan antara kebijakan dan administrasi menimbulkan pertanyaan pada diskresi pada pihak administrasi. Di era reformasi administrasi berisi ragam diskresi yang membuka teknis dan efisiensi administrative.Lebih mendalam kebijakan dan administrasi adalah "firewall".

Kritik secara empiris perbedaan antara kebijakan dan administrasi menurut kingdom, 1995; Bardach 1977 yang dikutip oleh Frederickson dan Smith (2003) bahwa birokrat sering ikut dalam pembuatan agenda kebijakan dan pembuatan kebijakan dan bahwa pejabat terpilih seringkali terlibat dengan apa yang di deskripsikan sebagai manajemen atau administrasi (Gilmour dan Halley, 1994). Dari teori tersebut dapat dijelaskan bahwa birokrasi seringkali bermain untuk saling mencampuri pada ranah kebijakan sehingga menurut Wilson dikatakan secara jelas ada sedikit campur tangan yang dilakukan oleh birokrat ke urusan kebijakan dan juga dilakukan oleh politisi ke dalam administrasi. Oleh karena itu dikotomi dikatakan sebagai kontinum kebijakan administrasi (Etzioni, 1961).

Dari model ini memperlihatkan ada kontrol politik atas birokrasi.Akan tetapi kontrol tersebut masih terbatas dan kontigen seperti halnya ada kontrol birokratik ke kebijakan dan kontrol politik ke administrasi.Model general seperti ini memiliki tujuan untuk menjelaskan kebijakan dengan bentuk model lainnya secara verbal, matematik dan grafik.

Selanjutnya dalam penelitian yang dilakukan James H. Svara yang dikutip oleh oleh Frederickson dan Smith (2003) menunjukan model bauran dalam kebijakan hubungan antara pejabat terpilih dan administrator. Dari model bauran dalam kebijakan menunjukan pengaruh dari beberapa pakar diantaranya David Easton (1965), Robert Dahl (1947), Wallace sayer (1958) mendefinisikan politik dan administrasi sebagai distribusi nilai, biaya, dan keuntungan. Politisi dan birokrat secara keseluruhan ikut dalam proses distribusi ini dan didalamnya administrator berpeluang membuat proposal - proposal pemberi kebijakan, menggunakan diskresi, menulis budget dan menentukan proses pemberian jasa dan lewat implementasinya, mereka membentuk kebijakan yang dirumuskan pejabat terpilih (Svara, 1994).

Kemudian penting untuk membedakan fungsi proses administrasi tanpa mempertimbangkan siapa yang membuatnya. Menurut James H. Svara yang dikutip oleh Frederickson dan Smith (2003) membuat model empat bagian dengan memecah dikotomi dengan menggunakan empat kategori aktivitas pemerintah dan mendiskripsikan tugas pejabat politik dan birokrat dalam setiap kategori, seperti yang ada dalam kolom selanjutnya dibawah ini: 


\section{Gambar 1.}

Pembagian Dikotomi: Dimensi Proses Pemerintah

\begin{tabular}{|c|c|c|}
\hline Tugas Council & Lingkup Council & Tugas Administrator \\
\hline $\begin{array}{l}\text { Menentukan tujuan, } \\
\text { skop jasa, level } \\
\text { pajak, isu konstitusi }\end{array}$ & Misi & $\begin{array}{l}\text { Memberikan nasehat (apa } \\
\text { yang dapat dilakukan kota } \\
\text { bisa mempengaruhi apa } \\
\text { yang harus dilakukan } \\
\text { kota), menganalisa kondisi } \\
\text { dan trend }\end{array}$ \\
\hline $\begin{array}{l}\text { Menentukan } \\
\text { kordinasi, } \\
\text { menyetujui proyek } \\
\text { dan program baru, } \\
\text { meratifikasi budget }\end{array}$ & Kebijak & $\begin{array}{l}\text { Membuat rekomendasi } \\
\text { tentang semua keputusan, } \\
\text { merumuskan budget, } \\
\text { menentukan formula } \\
\text { distribusi jasa }\end{array}$ \\
\hline $\begin{array}{l}\text { Membuat } \\
\text { implementasi, misal } \\
\text { keputusan, seleksi } \\
\text { tempat, penanganan } \\
\text { keluhan, mengawasi } \\
\text { administrasi }\end{array}$ & Administrasi & $\begin{array}{l}\text { Menetapkan praktek dan } \\
\text { prosedur dan membuat } \\
\text { keputusan yang } \\
\text { mengimplementasikan } \\
\text { kebijakan }\end{array}$ \\
\hline $\begin{array}{l}\text { Menyarankan } \\
\text { perubahan } \\
\text { manajemen ke } \\
\text { manajer, mereview } \\
\text { kinerja organisasi } \\
\text { dalam penilaian } \\
\text { manajer }\end{array}$ & Manajemen & $\begin{array}{l}\text { Mengontrol sumberdaya } \\
\text { manusia, materi dan } \\
\text { informasi bagi organisasi } \\
\text { guna mendukung } \\
\text { kebijakan dan fungsi } \\
\text { administrative }\end{array}$ \\
\hline
\end{tabular}

Sumber: Frederickson dan Smith (2003)

Kemudian dalam level di pemerintahan daerah menurut Nalbandian et.al., yang dikutip oleh Frederickson dan Smith (2003) bahwa pejabat terpilih dan birokrat memiliki nilai berbeda. Pandangan peran dan aktivitas ini berbeda, meski tidak ada dikotomi politik dan administrasi, ternyata ada dikotomi nilai.Pejabat yang terpilih dan analis politik menganggap birokrasi di pemerintahan daerah berada diluar kontrol.Tapi kenyataannya memang tidak demikian.Hal ini tidak di luar kontrol tetapi dipengaruhi oleh nilai yang berbeda dari nilai politik biasanya.Sebagai bukti menunjukkan bahwa birokrat street level memiliki beberapa diskresi dalam implementasi kebijakan atau pengaruh dalam pembuatan kebijakan.

Arah dalam kontrol politik birokrasi yang telah menurut Steven Maynard moody et.al., (1995) yang dikutip oleh Frederickson dan Smith (2003) sebagian mereka mempelajari norma keputusan dari birokrat street level dan mempelajari keadilan bahwa: a). Birokrat street level cenderung menggunakan norma keadilan untuk memecah dilemma ketika ada tiga kondisi organisasi yaitu: 1. Birokrat street level merasa dia punya kontrol untuk menyelesaikan 
dilema; 2. Dia bekerja dalam budaya kerja yang mendorong proses diskresi birokrat street level; 3. Budaya kerja lokal menciptakan visi klien yang sebanding dengan cara birokrat street level dalam hubungan dengan klien, b). Birokrat street level yang bekerja dalam sebuah budaya kerja lokal yang mendorong penggunaan diskresi akan menggunakan beragam strategi untuk menentukan hasil ketika identifikasi klien cenderung kuat, tetapi berkonflik dengan budaya kerja lokal, c). Birokrat street level yang dijalankan dalam lingkungan yang menghambat diskresi dan memberikan batasan pada kemampuan birokrat street level untuk mengontrol situasi bisa menggunakan strategi tindak lanjut untuk memenuhi kebutuhan kerja, d). Birokrat street level yang bekerja di organisasi berbeda dalam area kebijakan yang sama akan menunjukan pola berbeda dalam menyelesaikan dilemma keadilan karena perbedaan budaya kerja dan identitas lokal.

\section{Teori Politik Birokrasi}

Dalam teori politik birokrasi ini menjelasakan peran pembuat kebijakan (making policy) dari administrasi dan birokrasi. Pemikiran ini secara eksplisit menolak dikotomi politik administrasi yang mendasari teori kontrol birokrasi seperti yang dijelaskan dalam bahasan sebelumnya diatas yang memandang pembagian semacam ini sebagai kemudahan dalam analisis yang memberikan penegasan adanya sebuah biaya (cost) akibat terlalu tajam dari perkembangan teori yang ada. Secara spesifik dapat dijelaskan membuat teori lebih bisa dipahami dengan melakukan pemisahan administrasi dari politik menghasilkan ketidaktahuan tentang peran utama birokrasi dalam struktur kekuatan politik. Karena birokrasi dan birokrat terlibat dalam perilaku politik sehingga kebutuhan untuk mempertanggungjawabkan peran politik birokrasi secara teori tetap ada.

Politik menurut Easton (1965) dan Lasswell (1936) yang dikutip oleh Frederickson dan Smith (2003) adalah alokasi otoritatif nilai atau proses memutuskan siapa mendapat apa, kapan dan bagaimana. Sejumlah hasil studi menunjukan sebagaimana yang dinyatakan oleh Meier (1993) bahwa birokrat dan birokrasi secara rutin mengalokasikan nilai dan memutuskan siapa mendapat apa, atau birokrasi secara logis terlibat dalam "politik tingkat satu". Sehingga dengan demikian Waldo (1948) memberikan sebuah kesimpulan bahwa administrasi bukanlah sebuah teknis dan netral nilai yang dipisahkan dari politik dan administrasi adalah "Politik".

Dari teori - teori yang dijelaskan di atas bahwa teori politik birokrasi berupaya menentang pembagian/pemisahan administrasi dan politik.Sehingga yang muncul ada upaya untuk menarik administrasi ke dalam sistematik politik, secara teoritis kurang menjelaskan peran politik dari birokrasi.Banyak pakar yang mendukung pembagian politik administrasi sangat mengetahui peran yang dimaikan birokrasi dan rigiditas pembagian yang diterima oleh para penerusnya. Menurut Wilson dan Goodnow yang dikutip oleh Lynn (2001) bahwa menuliskan idenya pada saat birokrasi publik mengalami kematangan patronase, tidak ada kompetisi dan korupsi menjelaskan bahwa politik dan administrasi 
menggambarkan sebuah sintesis daripada dua bagian yang terpisah dari kebijakan publik.

Jadi dapat disimpulkan administrasi harus menjelaskan mengenai politik, keduanya dibutuhkan dalam menjalankan peran yang riil dari birokrasi, terutama di pemerintahan pusat dan daerah, serta menjadi elemen yang penting untuk membangun kerangka pemikiran dari kajian disiplin keilmuan tersebut.

\section{POLA HUBUNGAN BIROKRASI DENGAN POLITIK}

Menurut Marie Fainsond pola hubungan birokrasi dengan politik adalah sebagai berikut:

1. Representative Bureaucracy, dimana birokrasi bersikap responsive terhadap para pemimpin politik dan tentu saja terhadap kemauan politik masyarakat, setiap prakarsa yang diambil oleh birokras didasarkan kesadaran terhadap consensus - consensus yang berlaku.

2. A part state Bureaucracy, dimana birokrasi yang terbentuk didalam negara menganut system partai tunggal. Birokrasi negara dikontrol oleh aparatur partai.

3. The military dominated Bureaucracy, dimana birokrasi yang tumbuh didalam suatu negara yang angkatan bersenjatanya mendominasi jabatan - jabatan politik di bidang eksekutif.

4. A personal instrument of the Autocrative, dimana suatu kondisi hubungan yang menempatkan para birokrat semata mata sebagai alat penguasa otokratis atau dictator. Pengaruh yang dimiliki oleh para birokrasi secara individual akan sangat bergantung pada kualitas yang dibutuhkan oleh penguasa.

5. Colonial administration on nominal rulling person or group, dimana birokrasi dapat memerintah baik secara langsung sebagai administrator colonial atau secara tak langsung atas nama seseorang atau sekelompok pengusaha.

Dari penjelasan diatas relasi birokrasi dan lembaga politik seharusnya dipisahkan antara domain masing - masing seperti halnya yang diungkapkan oleh Wilson (1887) dan Goodnow (1900) menyatakan perlu memisahkan antara administrasi dan politik yang arahnya adalah menjaga agar masing masing bertugas dan berfungsi sebagai sebagaimana mestinya sesuai system, norma, dan regulasi yang ada.

\section{PELAKSANAAN KEBIJAKAN PUBLIK}

Sebagaimana yang dijelaskan diatas bahwa usulan kebijakan yang telah diterima dan disahkan oleh pihak yang memiliki kewenangan dalam hal ini lembaga legislative, maka keputusan kebijakan telah siap untuk di implementasikan. Menurut Lowi (1972) dalam Crosby dan Brinkerhoff mengklasifikasikan kebijakan menjadi empat jenis, yang masing-masing memiliki pola biaya dan manfaat yang berbeda:

i. Distribusi, (subsidi, tatanan infrastruktur)

ii. Peraturan (peraturan industri, pengendalian pencemaran)

iii. Redistributif (pajak dan kebijakan kesejahteraan sosial)

iv. Konstitutif (prosedur).

Menurut argumennya bahwa jenis kebijakan menentukan dinamika politik dan 
dinamika kelompok kepentingan yang terjadi selama perumusan pelaksanaan kebijakan, Grindle dan Thomas (1991) menguraikan varian pada perspektif ini, dan memeriksa persyaratan biaya dan manfaat kebijakan, mereka melihat sebuah kebijakan dan bagaimana dan di mana politik seputar kebijakan tersebut berjalan. Kami melihat perbedaan ini tersebut meliputi: (a) membedakan tingkat kesulitan implementasi dan kompleksitas antar kebijakan; (b) membantu para pengelola kebijakan untuk memutuskan di mana harus mencari dari segi aktor mana yang akan mereka berinteraksi, dan di mana interaksi tersebut mungkin terjadi; (c) menantisipasi kemungkinan jumlah pemenang dan pecundang.

Disamping diatas perlu diketahui bersama sebab mengapa setiap warga negara perlu untuk mengetahui dan melaksanakan kebijakan publik. Menurut Anderson menjelaskan sebagai berikut, yaitu: a). Respek anggota masyarakat terhadap otoritas dan keputusan - keputusan badan/lembaga pemerintah; b). Adanya kesadaran untuk menerima kebijakan; c). Adanya keyakinan kebijakan itu dibuat secara sah, konstitusional dan dibuat oleh pejabat pemerintah yang berwenang yang melalui prosedur yang berlaku; d). Adanya kepentingan pribadi; e). Adanya hukuman - hukuman tertentu apabila tidak melaksanakan kebijakan; e). Masalah waktu (kalau masyarakat melihat kebijakan itu kontroversial maka aka nada penolakan kebijakan tersebut).

Selanjutnya Anderson juga menyatakan faktor - faktor yang menyebabkan orang tidak mematuhi kebijakan dan melaksanakan kebijakan sebagai berikut: a) Kebijakan bertentangan dengan system nilai masyarakat; b). Adnya konsep ketidakpatuhan selektif terhadap hukum; c). Keanggotaan seseorang dalam suatu perkumpulan atau kelompok; d). Keinginan untuk mencari untung dengan cepat; e) Adanya ketidakpastian hukum. Jadi peran lembaga birokasi/eksekutif memiliki peran yang sangat besar untuk mematuhi dan melaksanakan setiap kebijakan yang telah menjadi keputusan secara bersama secara konstitusi.

\section{PENUTUP}

Dikotomi politik administrasi diawali perkembangan kajian administrasi publik modern.Dikotomi dalam pemisahan power legislative dan eksekutif memberikan kerangka pemikiran dan asumsi penting dalam teori kontrol birokrasi.Sehingga administrasi harus menjelaskan mengenai politik, keduanya dibutuhkan dalam menjalankan peran yang riil dari birokrasi, terutama di pemerintahan pusat dan daerah, serta menjadi elemen yang penting untuk membangun kerangka pemikiran dari kajian disiplin keilmuan tersebut.

Dalam system relasi birokrasi dan lembaga politik seharusnya dipisahkan antara domain masing - masing, agar supaya antara administrasi dan politik memiliki arah untuk menjaga agar masing - masing mempunyai tugas dan fungsi sebagai sebagaimana mestinya sesuai system, norma, dan regulasi yang ada.Jadi peran lembaga birokasi/eksekutif mempunyai peran yang sangat besar untuk mematuhi keputusan dan melaksanakan setiap kebijakan yang telah menjadi kesepakatan bersama secara 
konstitusi bagi stakeholders (pemangku kepentingan) yang terkait.

\section{DAFTAR PUSTAKA}

Anderson, James E, 1979. Public Policy

Making. Holt, Rinehart and Wiston, New York

Blau, Peter dan Marshall W. Meyer., 1987.Birokrasi Dalam Masyarakat

Modern. Universitas Indonesia: Jakarta

Brinkerhoff Derick W dan Crosby, Benyamin

L., 2002.Managing Policy Reform.

Kumarian Press: USA

Dun, William. 1994. Public Policy Analysis,

PNew Jersey: rentice hall international

Inc Englewood Cliffs

Dahl, Robert. 1978. Modern Political

Analysis. Prentice Hall of India Private

Limited

Frederickson, G dan Smith, Kevin B, (2003).The Public Administration

Theory Primer, Westview Press:

Member of The Perseus Book Group

Gie, The Liang. 1973. Ilmu Politik.

Yogyakarta: Penerbit Karya

Hewlett, Micahel, and Ramesh, 1995.Studying

Public Policy: Policy Cycles and Public

Subsystem, Oxford University Press

Jones, C.O., 1977. An Introduction to The

Study of Public Policy, Massachusetts:

Duxbury Press

Ripley, Randall B, 1995. Analysis in Political

Science. Nelson Hall Publisher, Chicago. 